\title{
Analysis of 22 Elements in Milk, Feed, and Water of Dairy Cow, Goat, and Buffalo from Different Regions of China
}

\author{
Xuewei Zhou ${ }^{1,2} \cdot$ Xueyin $\mathrm{Qu}^{1,2} \cdot$ Shengguo Zhao ${ }^{1,2}$. Jiaqi Wang ${ }^{1,2} \cdot$ Songli $\mathrm{Li}^{1,2}$. \\ Nan Zheng ${ }^{1,2}$
}

Received: 5 June 2016 / Accepted: 8 August 2016/Published online: 22 August 2016

(C) Springer Science+Business Media New York 2016

\begin{abstract}
The objectives of this study were to measure the concentrations of elements in raw milk by inductively coupled plasma-mass spectrometry (ICP-MS) and evaluate differences in element concentrations among animal species and regions of China. Furthermore, drinking water and feed samples were analyzed to investigate whether the element concentrations in raw milk are correlated with those in water and feed. All samples were analyzed by ICP-MS following microwaveassisted acid digestion. The mean recovery of the elements was $98.7 \%$ from milk, $103.7 \%$ from water, and $93.3 \%$ from a certified reference material (cabbage). Principal component analysis results revealed that element concentrations differed among animal species and regions. Correlation analysis showed that trace elements $\mathrm{Mn}, \mathrm{Fe}, \mathrm{Ni}, \mathrm{Ga}, \mathrm{Se}, \mathrm{Sr}, \mathrm{Cs}$, U in water and $\mathrm{Co}, \mathrm{Ni}, \mathrm{Cu}, \mathrm{Se}, \mathrm{U}$ in feed were significantly correlated with those in milk $(p<0.05)$. Toxic and potential toxic elements $\mathrm{Cr}, \mathrm{As}, \mathrm{Cd}, \mathrm{Tl}, \mathrm{Pb}$ in water and $\mathrm{Al}, \mathrm{Cr}, \mathrm{As}, \mathrm{Hg}, \mathrm{Tl}$ in feed were significantly correlated with those in milk $(p<0.05)$. Results of correlation analysis revealed that elements in water and feed might contribute to the elements in milk.
\end{abstract}

Xuewei Zhou and Xueyin Qu contributed equally to this work.

Nan Zheng

zhengnan_1980@126.com

Xuewei Zhou

zhouxuewei@126.com

1 Ministry of Agriculture Laboratory of Quality \& Safety Risk Assessment for Dairy Products, Institute of Animal Science, Chinese Academy of Agricultural Sciences, Beijing 100193, People's Republic of China

2 State Key Laboratory of Animal Nutrition, Institute of Animal Science, Chinese Academy of Agricultural Sciences, Beijing 100193, People's Republic of China
Keywords Milk · Cow · Goat - Buffalo · Trace elements · ICP-MS

\section{Introduction}

Milk and milk products represent an important source of macro and micronutrients, including minerals. Trace elements such as iron $(\mathrm{Fe})$, zinc $(\mathrm{Zn})$, copper $(\mathrm{Cu})$, and selenium $(\mathrm{Se})$ are essential in human metabolism, growth, and development [1], while toxic elements such as lead $(\mathrm{Pb})$ and cadmium $(\mathrm{Cd})$ induce mental retardation and cardiovascular diseases $[2,3]$. Therefore, element concentration in milk and milk products are indicative of their safety and nutritional value.

The concentrations of trace and toxic elements in raw cow milk vary significantly by region [4-6]. For example, $\mathrm{Pb}, \mathrm{Cd}$, and $\mathrm{Cu}$ concentrations are $47.45,1.68$, and $890.15 \mu \mathrm{g} / \mathrm{L}$, respectively, in raw milk from Croatia [7], and 5.23, 0.40, and $51.8 \mu \mathrm{g} / \mathrm{L}$, respectively, in raw milk from Spain [8]. Additionally, element concentration in milk varies by animal species $[3,9,10]$. Najarnezhad et al. have studied the concentration of $\mathrm{Pb}$ and $\mathrm{Cd}$ in ewe and cow milk; the results showed that $\mathrm{Pb}$ and $\mathrm{Cd}$ in ewe milk were significantly higher than those in cow milk [10]. Lin Bo [11] reported that the concentrations of $\mathrm{Fe}$ and $\mathrm{Zn}$ in buffalo milk were higher than those in cow milk.

The concentrations of elements in raw milk are also affected by animal forage, feed, and water [12-14]. Concentrations of health-beneficial elements, e.g., cobalt (Co), $\mathrm{Fe}, \mathrm{Zn}$, in milk are dependent on the animal species, feed, milk sample collection time, environmental conditions, and manufacturing processes $[15,16]$. Arsenic (As) and $\mathrm{Fe}$ in cow milk are possibly related to a higher consumption of concentration feed [6]. Potortì et al. have reported that elements in donkey milk were related with 
those in feed and water [17]. Cu levels in milk are attributed to feed $\mathrm{Cu}$ concentrations [18].

In China, cattle represents a vital part of the economy. Cattle breeding stock reached 14.9 million in 2012, contributing to approximately 38.75 million tonne of cow milk [19]. In 2014, the population of dairy goats was approximately 1.2 million, and goat milk was the second most important type of milk in China [20]. Buffalo milk, which represents an important source of income in southern China, had a yield of approximately 33,000 $\mathrm{t}$ in Guangxi province in 2012 [21].

There is little information on the concentrations of trace, potentially toxic, and toxic elements in goat and buffalo milk in China. The correlations of elements content between milk and feed, drinking water are also little. Therefore, the objectives of this study were to measure the concentrations of elements in raw milk by inductively coupled plasma-mass (ICPMS) and evaluate differences in element concentrations among animal species and regions. Furthermore, drinking water and feed samples were analyzed to investigate whether the element concentrations in milk are correlated with those in drinking water and feed.

\section{Materials and Methods}

\section{Instrumentation}

Vanadium (V), manganese (Mn), Fe, Co, nickel (Ni), Cu, Zn, gallium $(\mathrm{Ga})$, Se, rubidium $(\mathrm{Rb})$, strontium $(\mathrm{Sr})$, silver $(\mathrm{Ag})$, caesium $(\mathrm{Cs})$, barium $(\mathrm{Ba})$, uranium $(\mathrm{U})$, aluminum $(\mathrm{Al})$, chromium $(\mathrm{Cr}), \mathrm{As}, \mathrm{Cd}$, mercury $(\mathrm{Hg})$, thallium $(\mathrm{Tl})$, and $\mathrm{Pb}$ were measured by ICP-MS (7700x, Agilent, USA), which was equipped with a quadrupole hyperboloid, Scott double pass spray chamber, concentric nebulizer, and high matrix introduction (HMI) sample introduction system. A microwave dissolver (CEM Corporation, USA) with PTFE tubes was used for milk and feed sample digestion; the operating conditions of ICP-MS are presented in Table 1. Vessels used in the digestion were previously immersed in $20 \% \mathrm{HNO}_{3}(v / v)$ for at least $12 \mathrm{~h}$ and rinsed with ultrapure water.

\section{Preparation of Standard Solutions}

A mercury calibration solution was prepared from $10 \mathrm{mg} /$ L mercury standard solution (SPEX, USA), while the calibration solutions of the other 21 elements were prepared from $10 \mathrm{mg} / \mathrm{L}$ multi-element stock standard solution (SPEX). An internal standard solution was an aqueous multi-element standard solution containing $100 \mathrm{mg} / \mathrm{L}$ of $\mathrm{Li}, \mathrm{Sc}, \mathrm{Ge}, \mathrm{Rh}, \mathrm{In}, \mathrm{Tb}, \mathrm{Lu}$, and Bi (SPEX). The internal stock standard solution was further diluted and used to correct any fluctuations of the instrument due to the
Table 1 Operating conditions and measurement parameters for the ICP-MS

\begin{tabular}{ll} 
Parameter & \\
\hline $\begin{array}{l}\text { Nebulizer } \\
\text { Spray chamber }\end{array}$ & $\begin{array}{l}\text { Concentric nebulizer } \\
\text { Dual channel Scott type } \\
\text { Mass analizator }\end{array}$ \\
Quadruple \\
Ar pas flow rates & $1550 \mathrm{~W}$ \\
Plasma & $15 \mathrm{~L} / \mathrm{min}$ \\
Auxiliary & $1.10 \mathrm{~L} / \mathrm{min}$ \\
Lens voltage & $12.2 \mathrm{~V}$ \\
Scanning mode & Peak hopping \\
Dwell time & $45 \mathrm{~s}$ \\
Sample uptake rate & $0.15 \mathrm{~mL} / \mathrm{min}$ \\
Isotopes & ${ }^{45} \mathrm{Sc},{ }^{72} \mathrm{Ge},{ }^{103} \mathrm{Rh},{ }^{115} \mathrm{In},{ }^{159} \mathrm{~Tb},{ }^{175} \mathrm{Lu},{ }^{209} \mathrm{Bi}$
\end{tabular}

matrix. Cabbage certified reference material (CRM) was obtained from the National Institute of Metrology (GBW10014, China). Nitric acid (65\%, Sigma, USA) and hydrogen peroxide (30\%, Merck, Germany) were used in sample digestion. To maintain the same percentage of acid in the samples, the calibration solutions were diluted with $6 \%(v / v) \mathrm{HNO}_{3}$ for milk, $10 \%(v / v) \mathrm{HNO}_{3}$ for feed, and $1 \%(v / v) \mathrm{HNO}_{3}$ for water.

\section{Sample Collection and Digestion}

A total of 299 samples were analyzed, including 100 milk samples (20 cow milk samples from Shandong, 20 cow milk samples from Shaanxi, 20 goat milk samples from Shandong, 20 goat milk samples from Shaanxi, and 20 buffalo milk samples from Guangxi), 100 feed samples, and 99 water samples (feed and water samples were collected from the same sites as the milk samples). Feed samples were total mixed ration (TMR) and collected from where the animal feeding. All samples were collected in April and July of 2014.

Milk and water samples were stored in $200 \mathrm{~mL}$ polypropylene bottles at $-20{ }^{\circ} \mathrm{C}$. Water samples were preserved by acidification with $2 \mathrm{~mL} \mathrm{HNO}_{3}$. Feed samples were oven dried at $65{ }^{\circ} \mathrm{C}$ for $48 \mathrm{~h}$ and ground to a particle size of $1 \mathrm{~mm}$.

Milk $(1 \mathrm{~mL})$ was digested with $3 \mathrm{~mL} \mathrm{HNO}_{3}(65 \%)$ and $4 \mathrm{~mL} \mathrm{H}_{2} \mathrm{O}_{2}(30 \%)$ in polytetrefluoethylene (PTFE) tubes. Feed $(0.5 \mathrm{~g})$ was first added with $1 \mathrm{~mL}$ of ultrapure water, then digested with $5 \mathrm{~mL} \mathrm{HNO}_{3}(65 \%)$ and $2 \mathrm{~mL} \mathrm{H}_{2} \mathrm{O}_{2}$ $(30 \%)$. Water was mixed with $1 \% v / v \mathrm{HNO}_{3}$ prior to ICPMS analysis. Sample digestion was performed at room temperature in open vessels.

A MARS 6 microwave sample digestion system (MARS 6, CEM Corporation, USA) with a power of $1600 \mathrm{~W}$ was used 
for the digestion of milk and feed samples. The milk samples were digested according to the following program: (1) ramp time $5 \mathrm{~min}$, temperature $90^{\circ} \mathrm{C}$, hold time $5 \mathrm{~min}$; (2) ramp time $5 \mathrm{~min}$, temperature $150{ }^{\circ} \mathrm{C}$, hold time $10 \mathrm{~min}$; and (3) ramp time $5 \mathrm{~min}$, temperature $180^{\circ} \mathrm{C}$, hold time $20 \mathrm{~min}$. The feed samples were digested according to the following program: (1) ramp time $5 \mathrm{~min}$, temperature $90^{\circ} \mathrm{C}$, hold time $5 \mathrm{~min}$; (2) ramp time $5 \mathrm{~min}$, temperature $150^{\circ} \mathrm{C}$, hold time $10 \mathrm{~min}$; and (3) ramp time $5 \mathrm{~min}$, temperature $200{ }^{\circ} \mathrm{C}$, hold time $20 \mathrm{~min}$. Digested samples were allowed to cool to room temperature, transferred to polypropylene tubes (Corning, USA), and diluted to $50 \mathrm{~mL}$ with ultrapure water. Blanks, devoid of samples, were subjected to similar digestion procedures.

\section{Quality Assurance}

Limit of detection (LOD) and limit of quantification (LOQ) were calculated from three and 10 times, respectively, the standard deviation of the sample blank relative to the slope of the analytical curve. The digestion procedures were different for milk, water, and feed samples; therefore, LOD and LOQ were calculated separately. The digested milk, feed, and water samples were used in the calculation of LOD and LOQ [22], as shown in Table 2.

To assess the accuracy of the method, cabbage CRM and spiked samples were analyzed. The recovery of the elements from cabbage CRM and spiked samples is shown in Table 3. The recovery of 22 elements in water and milk samples was $94.3-123.3 \%$ and $91.4-113.4 \%$, respectively, except for $\mathrm{Hg}(86.5 \%$ in water and $71.0 \%$ in milk). For cabbage CRM, the recovery of 18 elements was 71.2 $114.8 \%$. The results of recovery accord with precision of quantitative methods [23].

\section{Statistical Analysis}

Element concentrations below LOD were replaced by half the value of the respective detection limits. The data were not normally distributed; therefore, non-parametric test was used in the analysis. Spearman rank correlation was used to determine the magnitude of the correlation among elements in milk, water, and feed samples. Data analyses were performed using SPSS 17.0 (IBM, USA). Statistical significance was set at $p<0.05$. Principal component analysis (PCA) was performed with Canoco 5.0.

Table 2 Detection limits of 22 elements in milk, feed, and water

\begin{tabular}{|c|c|c|c|c|c|c|}
\hline \multirow[t]{2}{*}{ Element } & \multicolumn{2}{|l|}{$\operatorname{Milk}(\mu \mathrm{g} / \mathrm{L})$} & \multicolumn{2}{|l|}{ Feed $(\mu \mathrm{g} / \mathrm{kg})$} & \multicolumn{2}{|l|}{ Water $(\mu \mathrm{g} / \mathrm{L})$} \\
\hline & LOD & LOQ & LOD & LOQ & LOD & LOQ \\
\hline $\mathrm{V}$ & $1.35 \times 10^{-2}$ & 0.04 & 0.05 & 0.16 & 0.04 & 0.12 \\
\hline $\mathrm{Mn}$ & 1.83 & 6.11 & 0.19 & 0.64 & 1.47 & 4.91 \\
\hline $\mathrm{Fe}$ & 9.83 & 32.76 & 9.40 & 31.33 & 6.25 & 20.85 \\
\hline Co & 0.03 & 0.11 & 0.06 & 0.21 & $1.15 \times 10^{-2}$ & 0.04 \\
\hline $\mathrm{Ni}$ & 0.12 & 0.41 & 0.15 & 0.51 & 0.13 & 0.43 \\
\hline $\mathrm{Cu}$ & 1.16 & 3.86 & 1.71 & 5.71 & 0.16 & 0.52 \\
\hline $\mathrm{Zn}$ & 3.16 & 10.53 & 1.51 & 5.02 & 1.65 & 5.50 \\
\hline $\mathrm{Ga}$ & $9.73 \times 10^{-3}$ & 0.03 & 0.04 & 0.12 & $5.49 \times 10^{-3}$ & 0.02 \\
\hline $\mathrm{Se}$ & 0.13 & 0.44 & 0.11 & 0.38 & 0.09 & 0.29 \\
\hline $\mathrm{Rb}$ & 4.03 & 13.45 & 1.44 & 4.82 & 0.05 & 0.15 \\
\hline $\mathrm{Sr}$ & 0.32 & 1.08 & 3.92 & 13.07 & 15.75 & 52.49 \\
\hline $\mathrm{Ag}$ & 0.20 & 0.66 & 0.05 & 0.16 & 0.03 & 0.10 \\
\hline Cs & 0.03 & 0.11 & 0.06 & 0.19 & 0.02 & 0.08 \\
\hline $\mathrm{Ba}$ & 0.29 & 0.97 & 0.59 & 1.96 & 11.26 & 37.52 \\
\hline $\mathrm{U}$ & 0.08 & 0.27 & 0.03 & 0.08 & 0.02 & 0.08 \\
\hline $\mathrm{Al}$ & 1.69 & 5.64 & 1.53 & 5.11 & 2.91 & 9.71 \\
\hline $\mathrm{Cr}$ & 0.82 & 2.74 & 0.39 & 1.28 & 0.07 & 0.24 \\
\hline As & 0.09 & 0.30 & 0.18 & 0.61 & 0.15 & 0.51 \\
\hline $\mathrm{Cd}$ & $2.89 \times 10^{-3}$ & 0.01 & $3.35 \times 10^{-3}$ & 0.01 & $2.88 \times 10^{-3}$ & 0.01 \\
\hline $\mathrm{Hg}$ & 0.22 & 0.73 & 0.47 & 1.57 & 0.09 & 0.32 \\
\hline $\mathrm{Tl}$ & $1.33 \times 10^{-2}$ & 0.04 & $4.13 \times 10^{-3}$ & 0.01 & $1.07 \times 10^{-2}$ & 0.04 \\
\hline $\mathrm{Pb}$ & 0.28 & 0.94 & 0.16 & 0.53 & 0.05 & 0.16 \\
\hline
\end{tabular}


Table 3 Spike recovery and quality control of certified reference material, cabbage

\begin{tabular}{|c|c|c|c|c|c|}
\hline \multirow[t]{2}{*}{ Element } & \multicolumn{2}{|l|}{ Recovery (\%) } & \multicolumn{3}{|c|}{ Certified reference material } \\
\hline & Water & Milk & $\begin{array}{l}\text { Certified values } \\
(\mu \mathrm{g} / \mathrm{kg})\end{array}$ & $\begin{array}{l}\text { Observed values } \\
(\mu \mathrm{g} / \mathrm{kg})\end{array}$ & Recovery (\%) \\
\hline $\mathrm{Al}$ & 123.3 & 103.6 & $-{ }^{\mathrm{b}}$ & $-{ }^{\mathrm{b}}$ & $-{ }^{\mathrm{b}}$ \\
\hline V & 105.1 & 100.1 & $-{ }^{\mathrm{b}}$ & $-{ }^{\mathrm{b}}$ & $-{ }^{\mathrm{b}}$ \\
\hline $\mathrm{Cr}$ & 103.7 & 97.4 & 1800 & 1616.80 & 89.8 \\
\hline $\mathrm{Mn}$ & 107.1 & 99.1 & 18,700 & $19,366.70$ & 103.6 \\
\hline $\mathrm{Fe}$ & 111.8 & 96.7 & 98,000 & $89,836.62$ & 91.7 \\
\hline Co & 96.2 & 97.7 & 89 & 63.34 & 71.2 \\
\hline $\mathrm{Ni}$ & 95.3 & 97.1 & 930 & 922.70 & 99.2 \\
\hline $\mathrm{Cu}$ & 94.3 & 94.7 & 2700 & 2190.18 & 81.1 \\
\hline $\mathrm{Zn}$ & 107.3 & 94.0 & 26,000 & $23,543.38$ & 90.5 \\
\hline $\mathrm{Ga}$ & 100.3 & 99.6 & $-{ }^{\mathrm{a}}$ & $-{ }^{\mathrm{a}}$ & $-{ }^{a}$ \\
\hline As & 100.6 & 104.2 & 62 & 56.82 & 91.7 \\
\hline $\mathrm{Se}$ & 101.3 & 113.4 & 200 & 229.66 & 114.8 \\
\hline $\mathrm{Rb}$ & 105.3 & 91.4 & 19,600 & $18,882.77$ & 96.3 \\
\hline $\mathrm{Sr}$ & 114.3 & 98.5 & 48,000 & $48,460.21$ & 101.0 \\
\hline $\mathrm{Ag}$ & 103.2 & 103.3 & $-{ }^{\mathrm{a}}$ & $-{ }^{\mathrm{a}}$ & $-{ }^{a}$ \\
\hline $\mathrm{Cd}$ & 100.1 & 99.7 & 35 & 36.60 & 104.6 \\
\hline Cs & 105.1 & 101.5 & 82 & 74.87 & 91.3 \\
\hline $\mathrm{Ba}$ & 112.3 & 104.1 & 12,000 & $11,321.96$ & 94.3 \\
\hline $\mathrm{Hg}$ & 86.5 & 71.0 & 10.9 & 10.56 & 96.9 \\
\hline $\mathrm{Tl}$ & 102.4 & 101.1 & 6.3 & 4.63 & 73.4 \\
\hline $\mathrm{Pb}$ & 103.2 & 100.6 & 190 & 173.92 & 91.5 \\
\hline $\mathrm{U}$ & 102.1 & 103.2 & 20 & 19.42 & 97.1 \\
\hline Mean $\pm \mathrm{SD}$ & $103.7 \pm 7.45$ & $98.7 \pm 7.49$ & & & $93.3 \pm 10.25$ \\
\hline
\end{tabular}

\section{Results and Discussion}

\section{Concentrations of Trace Elements in Milk Samples}

$\mathrm{Mn}, \mathrm{Fe}, \mathrm{Cu}, \mathrm{Zn}, \mathrm{Se}, \mathrm{Rb}, \mathrm{Sr}, \mathrm{Cs}$, and Ba were present in all milk samples (positive rate $100.0 \%$ ). In buffalo milk, Ga had a positive rate of $100.0 \%$ (Table 4 ). $\mathrm{V}$ was present in 50 $100 \%$ of all milk samples, and $\mathrm{Ga}$ and $\mathrm{U}$ were present in $50-100 \%$ of cow and goat milk samples (Table 4). Other elements had lower positive rates: $\mathrm{Ni}, \mathrm{Co}$, and $\mathrm{U}$ were present in 10.0 to $50.0 \%$ of all milk samples, goat milk, and buffalo milk, respectively. Ag had positive rate was lower than $10.0 \%$ in all milk samples. As a result of the large percentage range, the mean values were affected by the high concentrations of the elements, which contributed to mean values that were higher than the median values.

Mean values were compared with those previously reported. Values above LOD were used for mean value calculation. Fe and $\mathrm{Zn}$ concentrations in our cow milk samples were similar to those reported in cow milk from Northern Spain [6], but lower than those reported from
Turkey [24]. In this study, Zn concentrations in cow milk were similar to those in cow milk from Silesia [14] and higher than those from Pakistan [25]. Mostly, $\mathrm{Cu}, \mathrm{Co}$, and Mn concentrations were lower than those previously reported. In our study, $\mathrm{Cu}$ and $\mathrm{Co}$ concentrations were lower than those measured in cow milk from Northern Spain [6] and Turkey [14]. Similarly, Cu concentrations in cow milk from Croatia and Pakistan [7, 25], and Mn concentrations in cow milk from South Africa [2] were higher than those obtained in our study (Table 4). On the other hand, Mn concentrations were comparable to those obtained in cow milk from Northern Spain [6].

The trace elements in goat milk were lower than those previously reported (Table 4). $\mathrm{Fe}, \mathrm{Cu}$, and $\mathrm{Zn}$ concentrations in our goat milk samples were lower than those from Turkey [26] and Saudi Arabia [12]. Additionally, the concentrations of most elements in goat milk were higher than those in cow milk (Table 4), as previously reported [27-29]. In the present study, Zn concentration in buffalo milk was five times higher than that in buffalo milk from India, while Fe concentrations were similar between the two studies [30]. 


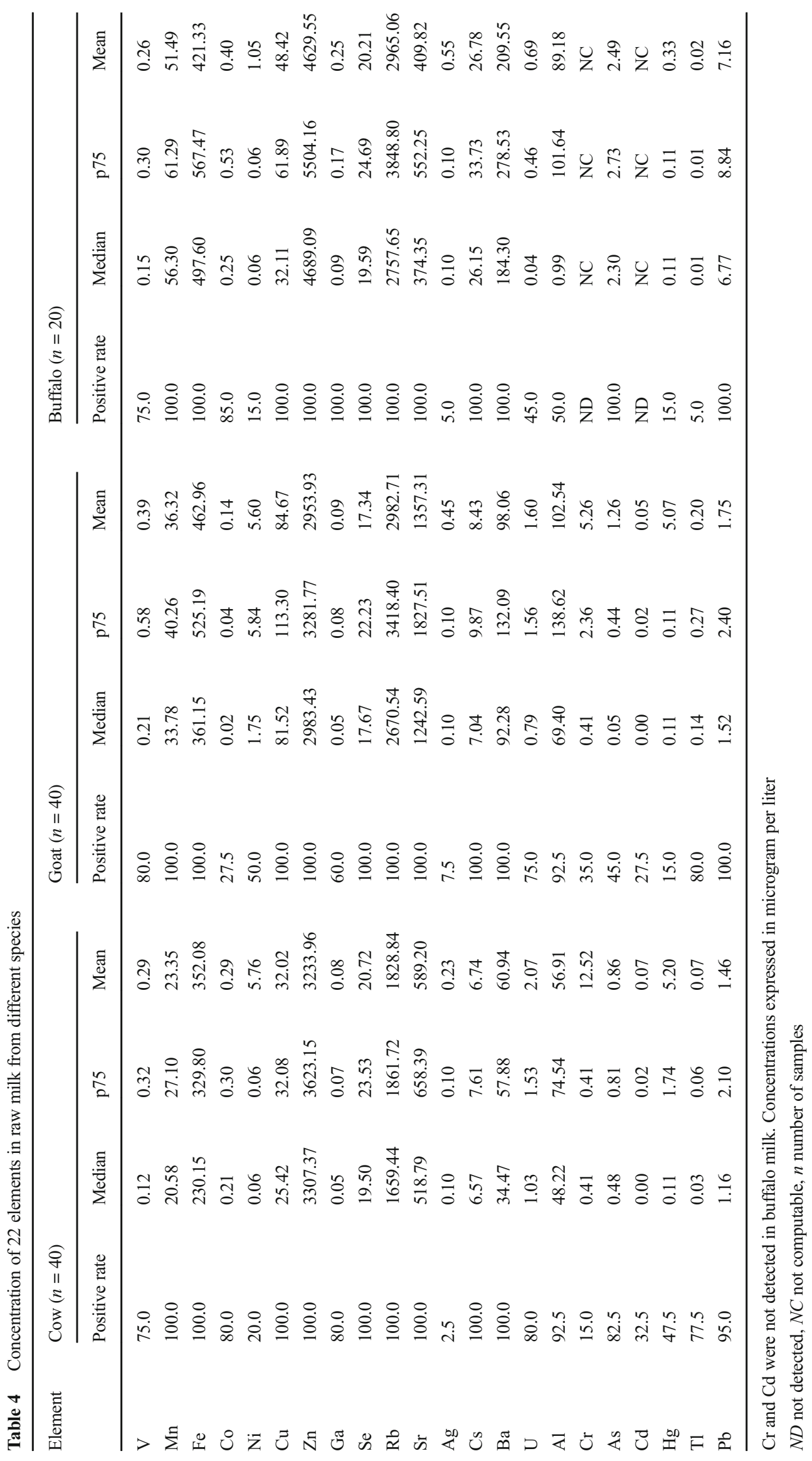




\section{Concentrations of Trace Elements in Drinking Water and Feed Samples}

The concentrations of trace elements in drinking water are presented in Table 5. Buffalo drinking water had higher trace element concentrations than those of cows and goats. Buffalo drinking water samples were collected from different province; therefore, region might account for such differences $[31,32]$. The concentrations of $\mathrm{V}, \mathrm{Co}, \mathrm{Ni}, \mathrm{Cu}, \mathrm{Ga}, \mathrm{Se}, \mathrm{Rb}$, and $\mathrm{Cs}$ in drinking water were lower than $10 \mu \mathrm{g} / \mathrm{L}$; Ag was not detected in any of the samples. The concentrations of $\mathrm{Mn}, \mathrm{Cu}$, and $\mathrm{Zn}$ in all drinking water samples were lower than those reported in northern Pakistan [32].

V, Mn, Fe, Co, Ni, Cu, Zn, Ga, Se, Rb, Sr, Cs, and Ba were present in $100 \%$ of all feed samples. Both Ag and U had positive rates of $100 \%$ in buffalo feed samples (Table 6). The concentrations of trace elements in feed samples were higher (tenfold) than those in drinking water (Tables 5 and 6).

\section{Concentrations of Toxic and Potential Toxic Elements in Raw Milk, Water, and Feed Samples}

The concentrations of toxic and potentially toxic elements ( $\mathrm{Al}$, $\mathrm{Cr}, \mathrm{As}, \mathrm{Cd}, \mathrm{Hg}, \mathrm{Pb}$, and $\mathrm{Tl}$ ) in milk samples are presented in Table 4. In cow milk, $\mathrm{Pb}$ had the highest positive rate (95.0 \%), followed by $\mathrm{Al}, \mathrm{As}$, and $\mathrm{Tl}$. $\mathrm{Cr}, \mathrm{Cd}$, and $\mathrm{Hg}$ had positive rates less than $50.0 \%$. In goat milk, $\mathrm{Pb}$ had the highest rate, followed by $\mathrm{Al}$ and $\mathrm{Tl}$, for $\mathrm{Cr}, \mathrm{Cd}, \mathrm{As}$, and $\mathrm{Hg}$ had the positive rate less than $50 \%$. In buffalo milk, $\mathrm{Pb}$ and $\mathrm{As}$ were detected in all samples (100.0\%), Al, Hg, and $\mathrm{Tl}$ were detected in less than $50 \%$ of the samples, and $\mathrm{Cr}$ and $\mathrm{Cd}$ were not detected.

The concentrations of toxic and potentially toxic elements in water and feed samples are presented in Tables 5 and 6, respectively. $\mathrm{Cr}$ was detected in all drinking water samples, and $\mathrm{Hg}$ was not detected. $\mathrm{Tl}$ had the lowest positive rate in cow and goat drinking water. The positive rate of the other elements in cow and goat drinking water was 47.5-87.5 \% . Al, $\mathrm{Pb}$, and $\mathrm{Cd}$ were present in $100.0 \%$ of buffalo water samples. For feed samples, $\mathrm{Al}, \mathrm{Cr}, \mathrm{As}, \mathrm{Cd}$, and $\mathrm{Pb}$ showed the highest positive rates. $\mathrm{Tl}$ had the highest positive rate in buffalo feed.

The results in Table 4 showed that $\mathrm{Cd}, \mathrm{Cr}$, and $\mathrm{Pb}$ concentrations in our cow milk samples were lower than those reported in Pakistan and Turkey, whereas As concentrations in our cow milk samples were higher than that reported in Turkey [24, 25, 33]. There were higher Cd concentrations in our cow milk samples than those reported in cow milk from South Africa [2]. Additionally, the concentrations of Al, Cd, $\mathrm{Cr}$, and $\mathrm{Pb}$ in goat milk were lower than those reported by Coni [15]. The concentrations of As in all drinking water samples were lower than those reported in Argentina [34]. Most of the toxic and potentially toxic elements detected in our samples were lower than those from other regions. Concentrations of $\mathrm{Pb}, \mathrm{Cr}, \mathrm{Hg}$, and $\mathrm{As}$ in all milk samples were below MRL established by China and the European Union (EU) [35]. Therefore, the raw milk samples used in this study had no health risks.

\section{Difference Analysis by Principal Component Analysis}

Figure 1 showed principal component $1 \times$ principal component 2 plots, where loadings and scores were simultaneously represented. PCA allowed the reduction of 17 variables to four PCs, which explained $68.12 \%$ of the total variance. The samples were collected from different animal species and regions. Element concentrations in milk and drinking water were analyzed by PCA to evaluate the effect of animal species and regions on raw milk element concentration.

The PCA results revealed that the concentrations of elements differed among animal species and regions (Fig. 1b), in agreement with the findings of Rahimi [3]. Similar results were obtained with drinking water. Element concentrations in water samples differed among regions. Element concentrations in buffalo water samples were different to those in cow and goat water samples, with no significant differences between cow and goat water samples (Fig. 1a). These results might be attributed to the location of sample collection. Cow and goat drinking water samples were collected from the same provinces, while buffalo water samples were collected from another distant region. The concentrations of elements in underground water from different regions are considerably different [32]. Differences in element concentrations in underground water might contribute to differences in element concentration in milk, water, and feed. PCA for feed samples revealed no significant differences among animal species or regions (data not shown).

\section{Correlation Analysis of Milk, Water, and Feed}

Trace elements Mn, Fe, Ni, Ga, Se, Sr, Cs, and U in milk were significantly correlated with those in drinking water, while $\mathrm{Co}, \mathrm{Ni}, \mathrm{Cu}, \mathrm{Se}$, and $\mathrm{U}$ were significantly correlated $(p<0.05)$ with those in feed (Table 7). Similarly, toxic and potentially toxic elements in milk were significantly correlated $(p<0.05)$ with those in water and feed. $\mathrm{Cr}, \mathrm{As}, \mathrm{Cd}, \mathrm{Tl}$, and $\mathrm{Pb}$ in milk had significant correlations with those in drinking water, while $\mathrm{Al}, \mathrm{Cr}, \mathrm{As}, \mathrm{Hg}$, and $\mathrm{Tl}$ in milk samples were significantly correlated with those in feed samples $(p<0.05$, Table 7).

Therefore, elements in drinking water and feed might contribute to the elements in milk. This result was consistent with previously reported correlations between elemental mass fractions in milk and ingested feed and water [16]. Fe contamination in drinking water may directly affect cow milk Fe 


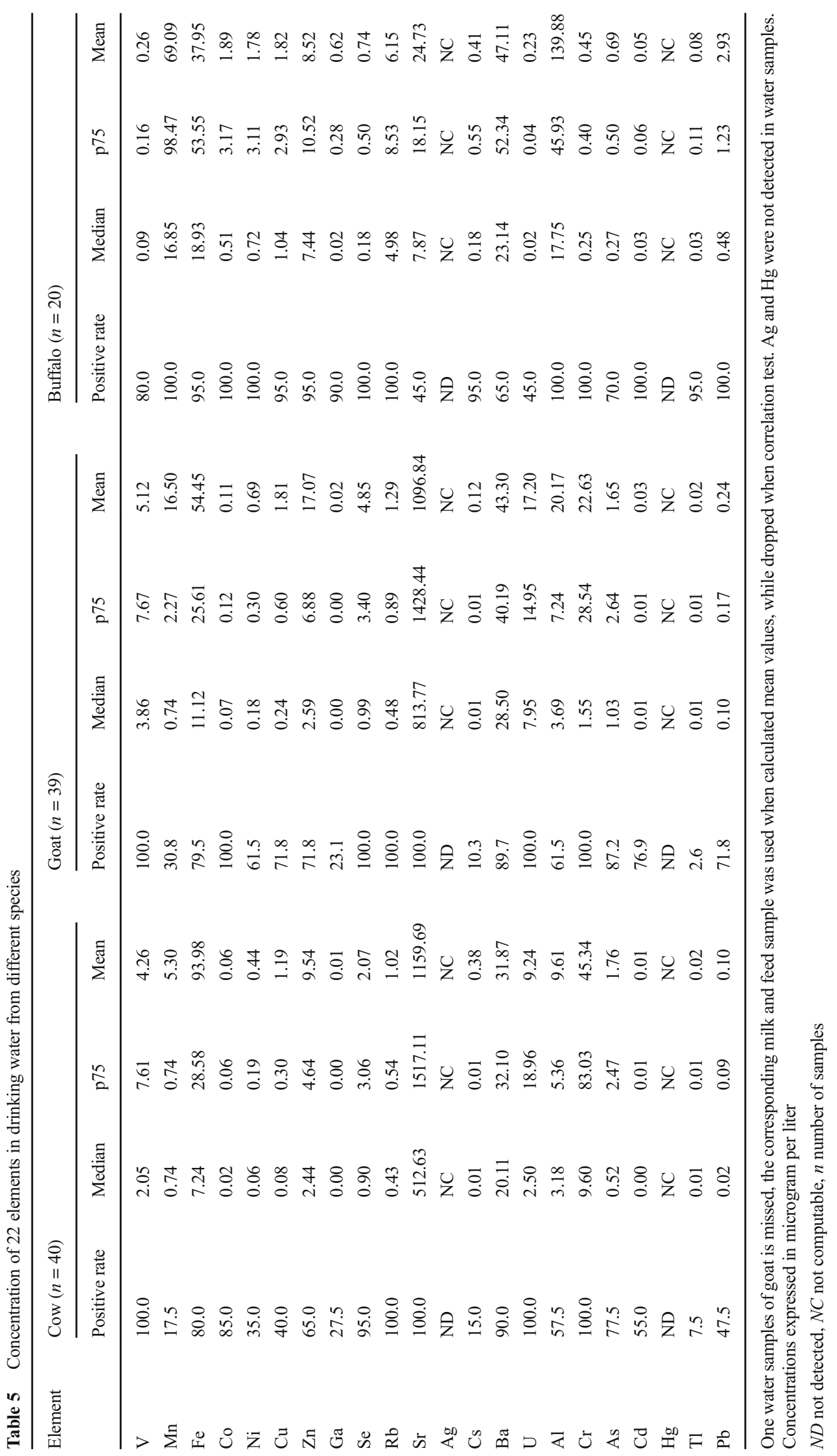




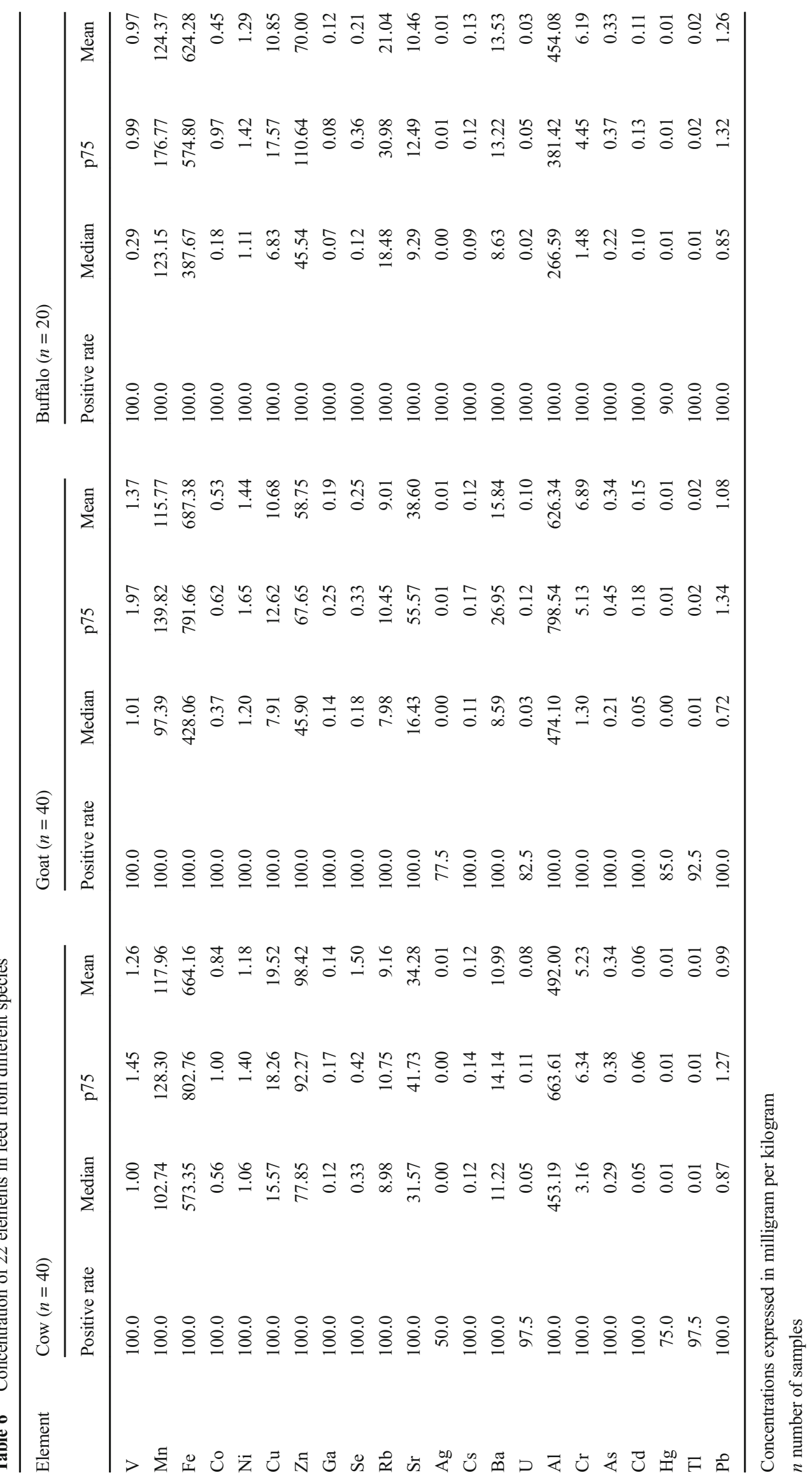


Fig. 1 The result of difference analysis by PCA for milk and water. $S D$ Shandong province, $S X$ Shaanxi province, $G X$ Guangxi province. $X$-axis is principal component 1 and $Y$-axis is principal component 2 . a The result of PCA for water samples. b The result of PCA for milk samples. Variables used in the principal component analysis were $\mathrm{V}, \mathrm{Se}, \mathrm{Ni}, \mathrm{Ga}, \mathrm{Rb}, \mathrm{Sr}, \mathrm{Ag}$, Cs, Ba, U, Al, Cr, As, Cd, Hg, Tl, and $\mathrm{Pb}$ in water and milk samples a

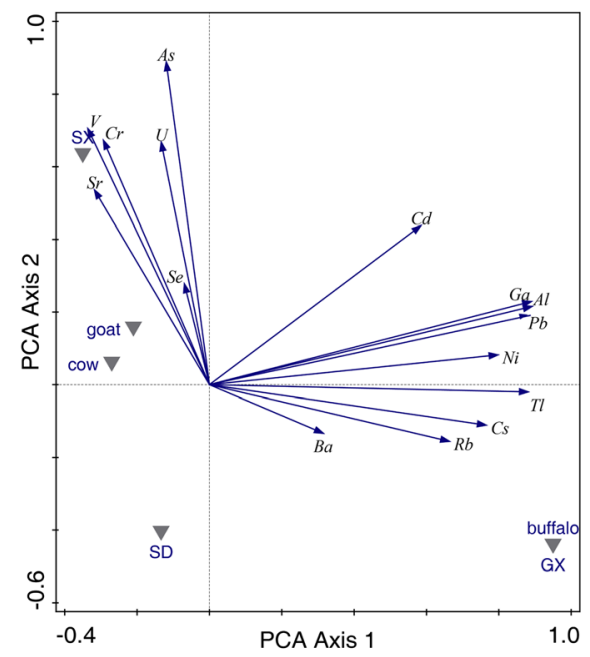

b

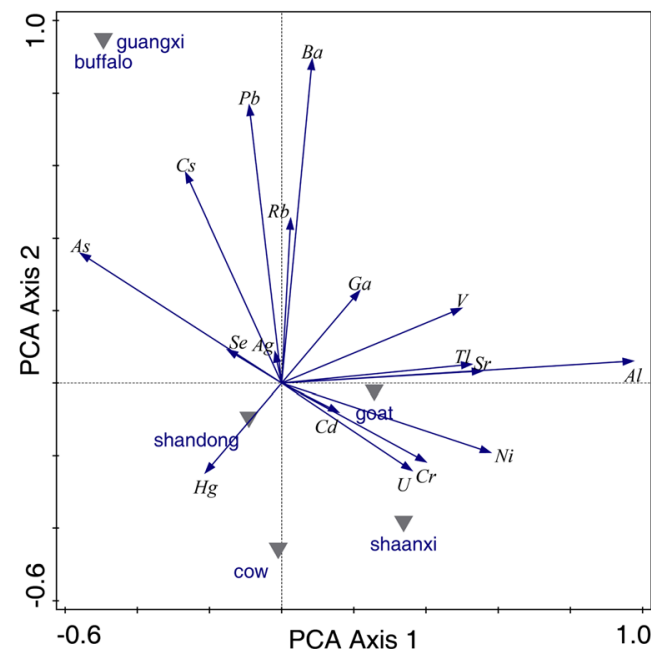

concentrations [36]. Deka [37] reported that Cr concentrations in milk is increased by adding $\mathrm{Cr}$ to the feed; however, As in drinking water showed a low biological transference to cow milk [34]. Compared to water, fewer elements in feed were significantly correlated with those in milk (Table 7). The feed of dairy animals is more likely to be collected from different regions rather than locally produced. On the other hand, drinking water is usually local.

Table 7 Correlation analysis of elements in milk with that in drinking water and feed

\begin{tabular}{|c|c|c|c|c|}
\hline \multirow[t]{2}{*}{ Element } & \multicolumn{2}{|l|}{ Water } & \multicolumn{2}{|l|}{ Feed } \\
\hline & $R$ & $p$ & $R$ & $p$ \\
\hline $\mathrm{Mn}$ & 0.421 & 0.000 & - & - \\
\hline $\mathrm{Fe}$ & 0.237 & 0.018 & - & - \\
\hline Co & - & - & 0.238 & 0.018 \\
\hline $\mathrm{Ni}$ & -0.369 & 0.000 & -0.321 & 0.001 \\
\hline $\mathrm{Cu}$ & - & - & -0.206 & 0.041 \\
\hline $\mathrm{Ga}$ & 0.261 & 0.009 & - & - \\
\hline $\mathrm{Se}$ & -0.210 & 0.037 & 0.365 & 0.000 \\
\hline $\mathrm{Sr}$ & 0.431 & 0.000 & - & - \\
\hline Cs & 0.512 & 0.000 & - & - \\
\hline $\mathrm{U}$ & 0.207 & 0.040 & 0.218 & 0.030 \\
\hline $\mathrm{Al}$ & - & - & -0.075 & 0.005 \\
\hline $\mathrm{Cr}$ & 0.481 & 0.000 & -0.228 & 0.023 \\
\hline As & -0.398 & 0.000 & 0.199 & 0.048 \\
\hline $\mathrm{Cd}$ & -0.252 & 0.012 & - & - \\
\hline $\mathrm{Hg}$ & - & - & 0.297 & 0.003 \\
\hline $\mathrm{Tl}$ & -0.483 & 0.000 & -0.237 & 0.018 \\
\hline $\mathrm{Pb}$ & 0.434 & 0.000 & - & - \\
\hline
\end{tabular}

$R$ correlation coefficient

$p$ statistically significant at $p<0.05$

$-p>0.05$, no relationship between milk and water or feed

\section{Conclusion}

There were differences in element concentrations based on animal species and regions. Drinking water samples from different regions had different element concentrations. On the other hand, there were no significant differences in element concentrations in feed samples among animal species or regions. Correlation analysis revealed that the concentrations of elements in water and feed might contribute to those in milk. From the correlation results, toxic and potentially toxic elements in raw milk were associated with those in feed and drinking water, which emphasizes the importance of element control in the feed and drinking water of dairy animals. However, further longitudinal studies are requires to clarify the way that element in drinking water and feed secreted into milk, especially toxic elements.

Acknowledgments This study was supported by the Special Fund for Agro-scientific Research in the Public Interest (201403071), the Modern Agro-Industry Technology Research System of the PR China (nycytx-0401 ), and the Agricultural Science and Technology Innovation Program (ASTIP-IAS12).

\section{Compliance with Ethical Standards}

Conflict of Interest All authors have approved the submission and none of the author declares any conflict of interest in the work performed or in the submission of the manuscript. 
2. Ataro A, McCrindle RI, Botha BM, McCrindle CME, Ndibewu PP (2008) Quantification of trace elements in raw cow's milk by inductively coupled plasma mass spectrometry (ICP-MS). Food Chem 111(1):243-248

3. Rahimi E (2013) Lead and cadmium concentrations in goat, cow, sheep, and buffalo milks from different regions of Iran. Food Chem 136(2):389-391

4. Król J, Litwiñczuk Z, Brodziak A, Kêdzierska-Matysek M (2012) Content of selected essential and potentially toxic trace elements in milk of cows maintained in Eastern Poland. Journal of Elemntology 17(4):597-608

5. Pilarczyk R, Wójcik J, Czerniak P, Sablik P, Pilarczyk B (2013) Concentrations of toxic heavy metals and trace elements in raw milk of Simmental and Holstein-Friesian cows from organic farm. Environ Monit Assess 185(10):8383-8392

6. Rey-Crespo F, Miranda M, López-Alonso M (2013) Essential trace and toxic element concentrations in organic and conventional milk in NW Spain. Food Chem Toxicol 55:513-518

7. Bilandžić N, Đokić M, Sedak M, Solomun B, Varenina I, Knežević Z, Benić M (2011) Trace element levels in raw milk from northern and southern regions of Croatia. Food Chem 127(1):63-66

8. Sola-Larrañaga C, Navarro-Blasco I (2009) Chemometric analysis of minerals and trace elements in raw cow milk from the community of Navarra, Spain. Food Chem 112(1):189-196

9. Al-Awadi FM, Srikumar TS (2001) Trace elements and their distribution in protein fractions of camel milk in comparison to other commonly consumed milks. J Dairy Res 68:463-469

10. Najarnezhad V, Akbarabadi M (2013) Heavy metals in raw cow and ewe milk from north-east Iran. Food Additives \& Contaminants Part B-Surveillance 6(3):158-162

11. Lin B, Li Y, Li L, Du HC, Tang Y, Nong HR, Zeng QK (2014) Analysis and comparation of minerals content in buffalo milk from different breeds. China Dairy Industry 42(3):15-17

12. Al-Wabel NA (2008) Mineral contents of milk of cattle, camels, goats and sheep in the central region of Saudi Arabia. Asian Journal of Biochemistry 3(6):373-375

13. Müller T, Feichtinger H, Berger H, Müller W (1996) Endemic tyrolean infantile cirrhosis an ecogenetic disorder. Lancet 347:877-880

14. Dobrzański Z, Kołacz R, Górecka H, Chojnacka K, Bartkowiak A (2005) The content of microelements and trace elements in raw milk from cows in the Silesian region. Pol J Environ Stud 14(5):685-689

15. Coni E, Bocca A, Coppolelli P, Caroli S, Cavallucci C, Marinucci MT (1996) Minor and trace element content in sheep and goat milk and dairy products. Food Chem 57(2):253-260

16. Herwig N, Stephan K, Panne U, Pritzkow W, Vogl J (2011) Multielement screening in milk and feed by SF-ICP-MS. Food Chem 124(3):1223-1230

17. Potortì AG, Bella GD, Turco VL, Rando R, Dugo G (2013) Nontoxic and potentially toxic elements in Italian donkey milk by ICPMS and multivariate analysis. J Food Compos Anal 31(1):161-172

18. Havemose MS, Weisbjerg MR, Bredie WLP, Poulsen HD, Nielsen JH (2006) Oxidative stability of milk influenced by fatty acids, antioxidants, and Cu derived from feed. J Dairy Sci 89:1970-1980

19. China, D.A.O (2014) 2014 China dairy statistical summary. Dairy Association of China, Beijing

20. Zhao S, Li Z, Dong Y, Gu X, Deng L, Guo C, Wang Y, Zhang S (2014) Strategy research on goats industry development and goat milk quality and safety condition in China. Quality and Safety of Agro-Products 6:12-15

21. Tang S (2014) Dairy buffalo industry developmental current situation and considerations in Guangxi. Journal of Guangxi Agriculture 29(1):50-55
22. D'Ilio S, Petrucci F, D'Amato M, Di Gregorio M, Senofonte O, Violante N (2008) Method validation for determination of arsenic, cadmium, chromium and lead in milk by means of dynamic reaction cell inductively coupled plasma mass spectrometry. Anal Chim Acta 624(1):59-67

23. EU. (2002). 2002/657/EC. Implementing Council Directive 96/23/ EC concerning the performance of analytical methods and the interpretation of results

24. Temiz H, Soylu A (2012) Heavy metal concentrations in raw milk collected from different regions of Samsun, Turkey. Int J Dairy Technol 65(4):516-522

25. Khan N, Jeong IS, Hwang IM, Kim JS, Choi SH, Nho EY, Choi JY, Park KS, Kim KS (2014) Analysis of minor and trace elements in milk and yogurts by inductively coupled plasma-mass spectrometry (ICP-MS). Food Chem 147:220-224

26. Güler Z (2007) Levels of 24 minerals in local goat milk, its strained yoghurt and salted yoghurt. Small Rumin Res 71:130-137

27. Jan FA, Ishaq $M$, Khan S, Shakirullah M, Asim SM, Ahmad I (2011) Bioaccumulation of metals in human blood in industrially contaminated area. J Environ Sci 23(12):2069-2077

28. Khan ZI, Ashraf M, Hussain A, McDowell LR, Ashraf MY (2006) Concentrations of minerals in milk of sheep and goats grazing similar pastures in a semiarid region of Pakistan. Small Rumin Res 65(3):274-278

29. Nestares T, Díaz-Castro J, Alférez MJM, López-Aliaga I, Barrionuevo M, Campos MS (2008) Calcium-enriched goat milk, in comparison with similarly enriched cow milk, favours magnesium bioavailability in rats with nutritional ferropenic anaemia. $\mathrm{J}$ Sci Food Agric 88(2):319-327

30. Shailaja M, Reddy YS, Kalakumar BD, Brinda SA, Manohar G, Kumar BD (2014) Lead and trace element levels in milk and blood of buffaloes (Bubalus bubalis) from Hyderabad, India. Bull Environ Contam Toxicol 92:698-702

31. Khan K, Khan H, Lu Y, Ihsanullah I, Nawab J, Khan S, Shah NS, Shamshad I, Maryam A (2014) Evaluation of toxicological risk of foodstuffs contaminated with heavy metals in Swat, Pakistan. Ecotoxicol Environ Saf 108:224-232

32. Khan K, Lu Y, Khan H, Zakir S, Ihsanullah, Khan S, Khan AA, Wei L, Wang T (2013) Health risks associated with heavy metals in the drinking water of Swat, north Pakistan. J Environ Sci 25(10): 2003-2013

33. Kazi TG, Jalbani N, Baig JA, Kandhro GA, Afridi HI, Arain MB, Jamali MK, Shah AQ (2009) Assessment of toxic metals in raw and processed milk samples using electrothermal atomic absorption spectrophotometer. Food Chem Toxicol 47:2163-2169

34. Mirna S, Horacio B, Rosa Repetti M (2010) Evaluation of the influence of arsenical livestock drinking waters on total arsenic levels in cow's raw milk from Argentinean dairy farms. Food Chem 121(2):487-491

35. EC. (2002). European commission decision (EC). 2002/32/EC of the European parliament and of the council of 7 May 2002 on undesirable substances in animal feed: European Journal of Communication

36. Mann GR, Duncan SE, Knowlton KF, Dietrich AD, O'Keefe SF (2013) Effects of mineral content of bovine drinking water: does iron content affect milk quality? J Dairy Sci 96(12):7478-7489

37. Deka RS, Mani V, Kumar M, Shiwajirao ZS, Kaur H (2015) Chromium supplements in the feed for lactating Murrah buffaloes (Bubalus bubalis): influence on nutrient utilization, lactation performance, and metabolic responses. Biol Trace Elem Res 168:362-371 